\title{
Retinoblastoma pN1 TNM Finding v7
}

National Cancer Institute

\section{Source}

National Cancer Institute. Retinoblastoma pN1 TNM Finding v7. NCI Thesaurus. Code C88742.

Retinoblastoma with regional lymph node involvement (preauricular, cervical). (from AJCC 7th Ed.) 